\title{
DEVELOPMENT OF STUDENT WORKSHEETS BASED ON GUIDED INQUIRIES TO TRAIN STUDENTS SCIENCE PROCESS SKILLS ON REACTION RATE MATERIALS
}

\author{
Haridha Nurfidayanti and Bertha Yonata \\ Chemistry Education Study Program, Faculty of Mathematics and Natural Sciences, Universitas Negeri \\ Surabaya, Surabaya, Indonesia \\ Email: haridhanurfidayanti@gmail.com
}

\author{
Accepted: January 02, 2022. Approved: January 10, 2022. Published: January 15, 2022
}

\begin{abstract}
The study aims to determine the validity, practicality, and effectiveness of the worksheets developed for the chemical learning of students' reaction rates. This research is focused on the guided inquiry learning model to improve students' science process skills. The research sample was 36 students of class 11 MIPA 4 SMAN 1 Puri, Mojokerto Regency. The research model used the One Group Pretest and Posttest Design. The data analysis technique used normality test, paired sample t-test, and n-gain test. The validation results show that 93.3\% is valid. An average of $98 \%$ of students showed a positive response to the developed Student Worksheets. In addition, students carry out relevant activities with $90.2 \%$ when learning takes place. The pretest-posttest of cognitive domains and science process skills showed what usually distributed the data. The paired sample t-test test showed a difference in the pretest-posttest results, and the n-gain test showed an increase in the pretest-posttest. The Student Worksheets Developed are valid, practical, and effective for use in learning chemistry for the Reaction Rate material and can train students' science process skills.
\end{abstract}

Keywords: Guided inquiry, Science process skills

\section{INTRODUCTION}

A curriculum is a tool used to achieve learning objectives in the education system in Indonesia [1]. Curriculum 2013 encourages students to actively participate in learning to improve and hone creativity according to their talents and interests [2]. The implementation of the 2013 curriculum aims to encourage students to master the competence of exemplary knowledge, attitudes, and skills in learning. Aspects of assessment applied to the 2013 curriculum are knowledge, attitudes and behavior, and skills.

One of the skills applied in 2013 curriculum-based learning is science process skills (SPS). SPS are process skills used to identify, define and solve a problem. [3]. Learning in chemistry subjects is knowing that refers to theory and practicum so that students can find concepts and facts from the given chemistry lesson. [4]. Even so, in learning chemistry at SMA Negeri 1 Puri, Mojokerto Regency, students have never done practicum since class $\mathrm{X}$, So their science process skills and skills in using laboratory equipment are deficient. The results of the pre-research on students of SMA Negeri 1 Puri also found that $85 \%$ of students did not understand the concepts and facts of chemistry learning, especially the Reaction Rate material. The learning applied is online learning, and in practice, students are only given learning videos that are difficult for students to understand. Therefore, it is necessary to train students' science process skills, especially on the Reaction Rate material.

The learning model used to train students' science process skills that are judged appropriate is the guided inquiry learning model. [5] A guided inquiry is a learning model that can help students learn and gain knowledge independently. With the application of the guided inquiry model, students can obtain and collect various information to find concepts and facts in chemistry learning [6].

The syntax of guided inquiry includes: focusing students' attention in conducting the inquiry process (investigation), describing an inquiry phenomenon, assisting students in formulating hypotheses according to the phenomenon, motivating students to collect data through hypothesis testing with a practicum process, formulating explanations, reflect on problems, and provide conclusions [7]. Guided inquiry syntax is closely related to indicators of science process skills. Indicators of science process skills include formulating problems, formulating hypotheses, identifying variables, conducting experiments, analyzing experimental data, and making conclusions.

In the era of the COVID-19 pandemic that has hit for one year, SMA Negeri 1 Puri decided to implement offline learning (face to face) with two sessions every day. Face-to-face learning with this 2 -session system has been going on for 1.5 months, with each session one subject lasting 45 minutes. Online learning is done without face-to-face but using application platforms such as zoom, google meet, google classroom, etc. [8]. Online learning leads to interaction between learners and teachers that can not be done directly. While offline learning is direct or conventional learning carried out by teachers by providing hardcopy materials and assignments with shorter study times. [9]. The transition from online learning to offline learning aroused the students' enthusiasm. It is because 
online learning often experiences obstacles such as unstable networks, less supportive facilities, etc., making students not understand the learning material well. Therefore, the re-application of offline learning must be accompanied by innovative learning. Teachers must develop learning tools to improve students' thinking skills, especially in science process skills. The practical learning tool used was Student Worksheet [4].
Student Worksheet maximizes students' conceptual abilities because it can improve the learning experience and independently find concepts through exploration in finding solutions to the problems given. The guided inquiry worksheets were considered the most effective method to improve science process skills and improve learning outcomes, knowledge, attitudes, and skills for learners, especially in chemistry [10].

Table 1. The relationship between the guided inquiry model and indicators of science process skills

\begin{tabular}{|c|c|c|}
\hline Guided Inquiry Syntax & Teacher Activities & $\begin{array}{l}\text { Science Process Skill's } \\
\text { Indicator }\end{array}$ \\
\hline $\begin{array}{l}\text { Focuses student's attention } \\
\text { and explains the process of } \\
\text { inquiry (investigation) }\end{array}$ & $\begin{array}{l}\text { The teacher prepares students } \\
\text { by explaining the learning } \\
\text { process that will be carried out. }\end{array}$ & \\
\hline $\begin{array}{l}\text { Presenting inquiry problems } \\
\text { or phenomena }\end{array}$ & $\begin{array}{l}\text { The teacher presents } \\
\text { phenomena related to the } \\
\text { material }\end{array}$ & $\begin{array}{l}\text { Formulate the problem } \\
\text { according to the } \\
\text { phenomenon }\end{array}$ \\
\hline $\begin{array}{l}\text { Helping students formulate } \\
\text { hypotheses } \quad \text { based } \\
\text { phenomena }\end{array}$ & $\begin{array}{l}\text { The teacher encourages } \\
\text { students to ask questions and } \\
\text { identify the appropriate } \\
\text { variables }\end{array}$ & $\begin{array}{l}\text { Develop hypotheses and } \\
\text { identify variables }\end{array}$ \\
\hline $\begin{array}{l}\text { Encourage students } \\
\begin{array}{l}\text { to test } \\
\text { hypotheses } \\
\text { observations }\end{array}\end{array}$ & $\begin{array}{l}\text { The teacher guides students in } \\
\text { conducting experiments } \\
\text { according to the procedure }\end{array}$ & Doing an experiment \\
\hline Formulating an explanation & $\begin{array}{l}\text { The teacher gives more in- } \\
\text { depth questions regarding the } \\
\text { experimental results and } \\
\text { learning materials }\end{array}$ & Analyze experimental data \\
\hline $\begin{array}{l}\text { Reflect on problem situations } \\
\text { and thought processes }\end{array}$ & $\begin{array}{l}\text { The teacher directs students to } \\
\text { make conclusions according to } \\
\text { the learning that has been done }\end{array}$ & Making conclusions \\
\hline
\end{tabular}

Based on this description, it is necessary to research "Development Of Student Worksheet Based on Guided Inquiries to Train Students' Science Process Skill's on Reaction Rate Materials."

\section{RESEARCH METHODS}

Before the study, the researchers conducted permits related to taking research data at SMA Negeri 1 Puri, Mojokerto Regency. After getting permission, the researcher asked for approval with the chemistry teacher to discuss the class and learners, which will be used for the research and research implementation schedule.

\section{Sample}

This research was conducted in SMAN 1 Puri, Mojokerto Regency, and the implementation time is carried out in November in the odd semester of the 2020/2021 academic year. The number of samples was 36 students of class XI MIPA 4, which were divided into six small groups in each session. The research was conducted on Reaction
Rate chemistry, the sub-chapter on factors that affect the rate of reaction.

\section{Instrument}

Research instruments are tools used to collect more complete data and information. The research instrument is used to measure the variable's value understudy will use the following research instruments [11]:

1. Validation Sheet

2. Student Response Questionnaire Sheet

3. Observation Sheet on Student Activity

4. Cognitive Domain Pretest-Posttest Sheet

5. Science Process Skills Pretest-Posttest Sheet

\section{Procedure}

This research uses the $R \& D$ research method (Research and Development Method). R \& D methods are efforts made to develop effective products for use in the world of education [12]. This research and development design uses a preexperimental design with One Group Pretest and Posttest Design to analyze the knowledge of 
students' process skills which has the following formulation:$$
\mathrm{O}_{1} \cdot \mathrm{X} \cdot \mathrm{O}_{2}
$$

Figure 1. Research One Group Pretest and Posttest Design [12]

Information :

1. $\mathrm{O}_{1}$ is generated of the scores obtained by students before using the developed student worksheets.

2. $\mathrm{O}_{2}$ is generated of the value obtained by students when using the developed student worksheets.

3. $\mathrm{X}$ is learning using Student Worksheets that have been developed.

This research was conducted in 3 stages: the preparation, implementation, and final stages.

1. Preparation phase

At this phase, several steps are carried out before conducting research. The preparation phase includes:

a. Make observations to the school to be researched

b. Conduct pre-research to schools by providing pre-research questionnaires

c. Designing devices and instruments in the learning process

d. Validate devices and instruments in the learning process

2. Implementation phase

In the implementation phase, research with learning activities in accordance with the syntax of the guided inquiry learning aims to improve students' science process skills. The implementation phase includes:

a. Give pretest questions to students

b. I applied the guided inquiry learning model to the reaction rate material based on the practicum.

c. I observed the Student Worksheet guided inquiry learning model during the learning process.

d. I am giving posttest questions to students

3. Final Stage

At the last stage, processing or analyzing the research data is carried out. The data research was obtained at the implementation stage. At this final stage, the data carried out the analysis aims to measure the level of success of researchers in training students' science process skills after developing Student Worksheet with the Guided Inquiry learning model. The data analyzed are all devices and instruments used in learning.

\section{Data Analysis}

Data analysis techniques are used to determine the achievement of research purposes. Data processing techniques in this study used descriptive analysis techniques. Where the descriptive analysis assessment technique is as follows:

1. Analysis of research results or revisions.

In this section, suggestions and input from lecturers and teachers are needed in improving and revising the shortcomings of the developed reaction rate worksheets.

2. Analysis of Student Worksheet Validation Results

The data from the validation results of the Student Worksheets on the reaction rate by two lecturers and two high school chemistry teachers were analyzed using a quantitative descriptive method to explain the Student Worksheet made with the percentage score found on the assessment sheet. The percentage of the questionnaire data was obtained from the scale calculation according to Likert.

Table 2. Likert Rating Scale [13]

\begin{tabular}{cc}
\hline Score & Evaluation \\
\hline 1 & Very Invalid \\
2 & Less Valid \\
3 & Quite Valid \\
4 & Valid \\
5 & Very Valid \\
\hline
\end{tabular}

Percentage $(\%)=\frac{\text { total } \text { skor } \text { result }}{\text { criteria } \text { skor }} \times 100 \%$

Student worksheets with guided inquiry to practice improving students' science process skills on the reaction rate material are valid for use if they can reach a percentage of $>61 \%$.

3. Analysis of Student Response Sheet Results

Answers to the questionnaire given by students after using the developed Student Worksheets were analyzed by percentage and concluded in descriptive sentences. The percentage of data obtained using calculations according to the Guttman rating scale with positive statements, namely:

Table 3. Guttman Rating Scale [14]

\begin{tabular}{cc}
\hline \multicolumn{2}{l}{ Guttman Scale } \\
\hline 1 & Yes \\
0 & No
\end{tabular}


Furthermore, the percentage of students' answers was calculation with the following formula.

$$
\mathrm{P}=\frac{F}{N} \mathrm{X} 100 \%
$$

Information:

$\mathrm{P}=$ Percentage of respondents' answers

$\mathrm{F}=$ Number of yes/no answers from respondents

$\mathrm{N}=$ Number of respondents

The Student Worksheets are said to be practical if the percentage of students who answered "yes" were $>61 \%$.

4. Analysis of Student Observation Sheet Results

The results of student observation during learning use the given student worksheets. Statements are made every 2 minutes for 45 minutes in 1 session, analyzed by percentage, and concluded in descriptive sentences. Three observers observed student activities were observed by three observers who monitored six students in each session.

The percentage of data was obtained using the following calculations.

number of students frequency

$$
\frac{\text { of activity }}{\text { number of activities }} \times 100 \%
$$

Then, the results of calculating the percentage of respondents' answers are reviewed for appropriateness with interpretation criteria. Student Worksheets are said to be practical if students' answers are $61 \%$.

5. Results analysis of the Knowledge Domain and Science Process Skills of Learners

Learning outcomes in the domain of students' knowledge are carried out by analyzing the answer to the pretest and posttest multiple choice questions as many as 15 questions if the correct answer is worth 1 . On the contrary, the wrong answer is worth 0 . Meanwhile, the questions are in essays containing six science process skills indicators. The scores were obtained from the test of learning outcomes in the realm of research and science process skills were analyzed in 3 stages, namely:

a. Normality test

The normality test conducted on the students' pretest-posttest scores aims to determine normal data. If it has a significance value (Sig.) $>0.05$, the study has a normal distribution.

b. Paired Test Sample T-Test

The data generated is normal, so the pretest-posttest values were analyzed using Paired Sample T-test.
This test determines the difference between the students' pretest-posttest scores. If the significance value (2Tailed) is $<0.05$, there is a difference between the pretest and posttest scores.

c. N-gain test

The pretest-posttest scores were then tested using $\mathrm{n}$-gain to determine the increase in students learning abilities. N-Gain can state how much improvement in the cognitive domain occurs because of the behavior performed. The following is the equation used :

$$
\begin{aligned}
& \qquad N \text {-Gain }=\frac{\text { Spost }- \text { Spre }}{\text { Smaks }- \text { Spre }} \\
& \text { Information } \\
& \text { N-Gain : Normalized gain } \\
& \text { Smax : The maximum value of } \\
& \text { the pretest and posttest } \\
& \text { Spre : Pretest score } \\
& \text { Spost : Posttest score } \\
& \text { N-Gain value is then averaged } \\
& \text { and interpreted into an increasing } \\
& \text { category, which can be seen in the } \\
& \text { table as follows: }
\end{aligned}
$$

Table 4. N-Gain Score Criteria [15]

\begin{tabular}{ccc}
\hline No & Value $(\mathrm{g})$ & Criteria \\
\hline 1 & $\mathrm{~g}<0.3$ & Low \\
2 & $0.7>\mathrm{g}>0.3$ & Enough \\
3 & $\mathrm{~g}>0.7$ & Tall \\
\hline
\end{tabular}

\section{RESULTS AND DISCUSSION}

The guided inquiry-based Student Worksheets Reaction Rate development aims to increase students' science process skills to 36 students of class XI SMAN 1 Puri, Mojokerto Regency. The learning process is carried out faceto-face, directly or offline, divided into two learning sessions.

The results of the research that has been carried out will be described and discussed as follows:

\section{Results of Validation of Learning Tools and Assessment Instruments}

The learning tools and assessment instruments used in the study were reviewed and assessed by four assessors, namely, two from the Chemistry Education Lecturer at the State University of Surabaya and two from the chemistry teacher at SMAN 1 Puri Mojokerto Regency. Student worksheets are validated to determine the validity of the tools and instruments used in learning, especially on student worksheets [20]. The validated indicators are as follows: 
Table 5. Validation Result Percentage Learning Tools and Assessment Instruments

\begin{tabular}{lc}
\hline \multicolumn{1}{c}{ Indicator } & $\begin{array}{c}\text { Validation Percentage } \\
(\%)\end{array}$ \\
\hline Conformity of Student Worksheets content & $83.57 \%$ \\
Suitability of Student Worksheets with the Guided Inquiry Method & $79.2 \%$ \\
Compatibility of Student Worksheets with skills being trained (SPS) & $79.2 \%$ \\
Standard Student Worksheet Presentation & $82 \%$ \\
Language Criteria in Student Worksheets & $85 \%$ \\
Student Worksheet Graphic Criteria & $83.3 \%$ \\
Compatibility of Syllabus and lesson plans & $82.5 \%$ \\
Suitability of Student Activity Observation Sheet & $81 \%$ \\
Appropriateness of pretest and posttest in Science Process Skills & $85 \%$ \\
Appropriateness of pretest and posttest in the knowledge domain & $85 \%$ \\
\hline
\end{tabular}

Based on table 5, the Student Worksheets and other instruments used have reached the validity criteria because the percentage results have reached $>61 \%$. Research tools and devices are valid if they reach $>61 \%$ [14]. The average percentage of the validity of the entire validation results is $93.3 \%$, stating that it is valid.

\section{Student Response}

Analysis of student responses aims to determine student responses to the Student Worksheets' practicality. The student response questionnaire contains 19 questions that have the suitability of the Student Worksheets developed. In addition, the response questionnaire contains student reviews about the learning carried out, especially when using student worksheets. The results of the answers were analyzed using the Guttman rating scale. If students answer "yes" then the score is 1 . but if students answer "no" then the score is 0 [14]. Students Worksheets are said to be practical if the percentage of students who answered "yes" > $61 \%$.

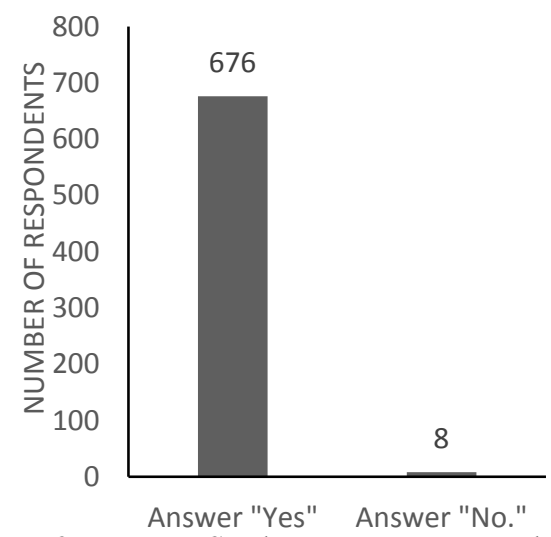

Figure 2. Data on Student Response Results

The student responses obtained an average of $98 \%$ of students answered "yes," and $2 \%$ answered "no." So from the results of the response, Student Worksheets is declared practical because the percentage is more than $61 \%$. Learning using guided inquiry using the given worksheets is proven to train the improvement of students' science process skills in accordance with the positive responses given by students. Guided inquiry can affect increasing students' science process skills [18]. The learning syntax of guided inquiry can shape students' science process skills.

\section{Student Activities}

Student observation aims to determine students' activities while using the provided Student Worksheets. In addition, the analysis of student activities serves to observe students' behavior in practicing science process skills during learning. Activities carried out by students during learning determine the practicality of the worksheets used. Observations were made by three observers who observed every six students every 2 minutes. The observed activities were ten relevant activities and one irrelevant activity. The appropriate activities observed were observing phenomena on the Student Worksheets, expressing opinions, paying attention to teacher explanations, formulating problems, determining variables, formulating hypotheses, identifying variables, conducting experiments, writing observations, analyzing data, and providing conclusions. Observable irrelevant activities are activities carried out by students in addition to 10 other relevant activities. The number of student activities is obtained from the number of appropriate activities carried out per the total number of activities.

From the study results, we obtained a percentage of $90.2 \%$ of relevant activities carried out by students and $9.8 \%$ of irrelevant activities carried out by students. The percentage of relevant activities carried out by students is more than $61 \%$, so the Student Worksheet has the practicality to use. The guided inquiry learning, student activity in learning will significantly increase, especially when doing a practicum.

\section{Student Cognitive Ability}

This research trains students' science process skills and trains the cognitive domain 
regarding the reaction rate material. The instrument used was a pretest sheet and a knowledge domain posttest sheet[17]. The questions are in the form of multiple-choice with factors that affect the rate of reaction and the order of the reaction. After the assessment is done, the student's test score data is tested for normality. The information is considered normal if a significance value $>0.05$ is obtained, but the data is abnormal if the significance value is $<0.05$.

Based on table 6 , the significance value obtained from the calculation is 0.654 , so it includes normal data because it has a significance value $>0.05$. The data has a normal distribution, and then the data obtained were tested using the Paired Sample T-Test. This test is to find out the difference between pretest and posttest scores. If the 2-tailed significance value is $<0.05$, there is a difference between the two tests. However, if the 2- tailed significance value is $>0.05$, there is no difference between the two tests.

Table 6. Normality Test Data for Learners' Cognitive Domains

\begin{tabular}{lll}
\hline & & $\begin{array}{l}\text { Non-standardized } \\
\text { Residual }\end{array}$ \\
\hline $\mathrm{N}$ & & 36 \\
Normal & Mean & $0 \mathrm{E}-7$ \\
Parameters $^{b}$ & Std. Deviation & 4,92636878 \\
most extreme & Absolute &, 122 \\
Differences & Positive &, 095 \\
Kolmogorov Smirnov $Z$ &,- 122 \\
Asymp.Sig. (2-tailed) &, 734 \\
\hline \multicolumn{2}{l}{ Negative } &, 654 \\
\hline
\end{tabular}

Table 7. Test Data Paired Sample T-Test

\begin{tabular}{|c|c|c|c|c|c|c|c|c|c|}
\hline & & \multicolumn{5}{|c|}{ Paired Differences } & \multirow{3}{*}{\multicolumn{2}{|c|}{$d f$}} & \multirow{3}{*}{$\begin{array}{c}\text { Sig. } \\
\text { (2-tailed) }\end{array}$} \\
\hline & & \multirow[t]{2}{*}{ mean } & \multirow[t]{2}{*}{$\begin{array}{c}\text { Std. } \\
\text { Deviation }\end{array}$} & \multirow[t]{2}{*}{$\begin{array}{l}\text { Std. } \\
\text { Error } \\
\text { Mean }\end{array}$} & \multicolumn{2}{|c|}{$\begin{array}{c}\text { 95\% Confidence } \\
\text { Interval of the } \\
\text { Difference }\end{array}$} & & & \\
\hline & & & & & Lower & Upper & & & \\
\hline Pair 1 & $\begin{array}{l}\text { PRETEST } \\
\text { POSTEST }\end{array}$ & $-32,92778$ & 8.74099 & 1.45683 & $-35,88530$ & -29.97025 & $-22,602$ & 35 & ,000 \\
\hline
\end{tabular}

Based on table 7 , the significance value obtained is 0.000 . It shows that there is a difference between the pretest and posttest results because it has a significance value of 2 tailed $<0.05$.

The third stage of testing the cognitive domain pretest and posttest data is the n-gain test. This test aims to analyze the increase in the realm of student knowledge. The following table shows the results of the rise in cognitive domain n-gain in 36 students.

Table 8 . The value of n-gain students' knowledge domain

\begin{tabular}{ccc}
\hline Many Students & Value & Category \\
\hline 10 & 0,61 & $\begin{array}{c}\text { High } \\
\text { enough } \\
\text { High }\end{array}$ \\
\hline
\end{tabular}

Based on table 8 , the increase in students' cognitive competence is good because the n-gain value is in the moderate and high categories. So that the guided inquiry Student Worksheets model provided is effectively used to help students obtain good learning outcomes. [19] said that guided inquiry learning can make students achieve the expected values and understand the material given very well.

\section{Students Science Process Skills}

This research was conducted to train students' science process skills on the reaction rate material. This ability was tested with pretest and posttest sheets. The questions are in the form of essays according to the science process skills and the reaction rate factors. The results of the research data tested for normality. Normal data has a significance value $>0.05$, but the data is said to be abnormal if the significance value is $<0.05$.

Based on table 9, the significance value is 0.86. Then the data is normal because the significance value is $>0.05$. The data obtained are normal, so the next test uses a paired sample t-test. This test was conducted to determine the difference before and after using student worksheets in learning, especially in science process skills. If the 2 -tailed significance value is $<0.05$, there is a difference between the two tests. However, if the 2tailed significance value is $>0.05$, there is no difference between the pretest and posttest scores. 
Table 9. Normality Test Data for Students' Science Process Skills

\begin{tabular}{lll}
\hline & & $\begin{array}{l}\text { Non- } \\
\text { standardized } \\
\text { Residual }\end{array}$ \\
\hline $\mathrm{N}$ & Mean & 36 \\
Normal & Std. & 5,63339683 \\
Parameters $^{b}$ & Deviation &, 7 \\
Most Extreme & Absolute &, 209 \\
Differences & Positive &, 108 \\
Kolmogorov-Smirnov Z &,- 209 \\
Asymp. Sig. (2-tailed) & 1,254 \\
\hline \multicolumn{2}{l}{ Astive } &, 086 \\
\hline
\end{tabular}

Based on table 10, obtained 2-tailed 0.000 showed a difference between the results of the pretest and posttest of science process skills because the 2-tailed significance value was $<0.05$.
The third stage of testing the data from the pretest and posttest in science process skills is the n-gain test. This test aims to measure the increase in students' science process skills. The following table shows the results of increasing n-gain in science process skills in 36 students.

Based on table 11, the students' science process skills improved well. The value of $n$-gain obtained in the category is relatively high and high. Thus, student worksheets used in learning have proven to be effective in helping students obtain good learning outcomes. Guided inquiry learning can encourage students to get good grades and understand the material in the learning [19]. The syntax of guided inquiry learning can improve students' science process skills. The guided inquiry learning process involves students investigating, identifying concepts or methods, and encouraging students' thinking in solving problems [18].

Table 10. Test Data Paired Sample T-Test

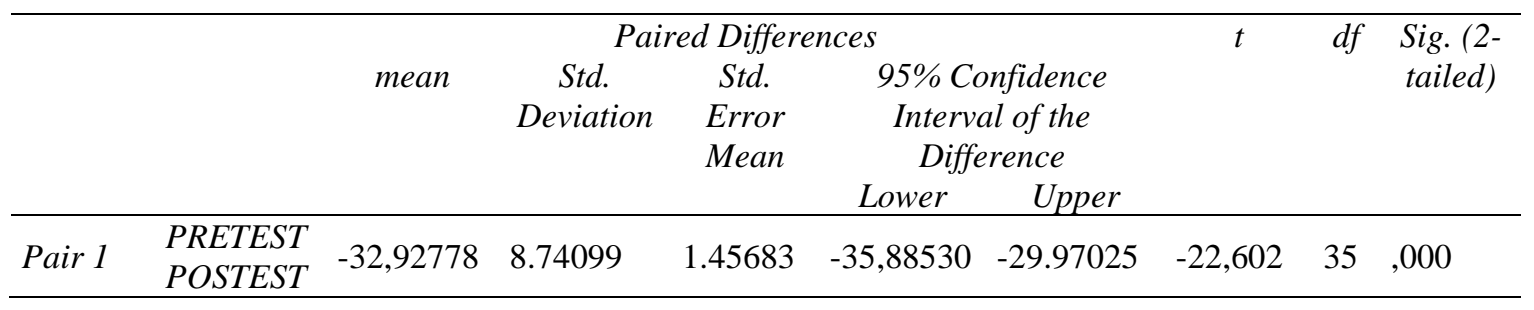

Table 11. The value of $n$-gain in the realm of students' science process skills

\begin{tabular}{ccc}
\hline Many Students & Value & Category \\
\hline 7 & 0,57 & $\begin{array}{c}\text { High } \\
\text { enough } \\
\text { High }\end{array}$ \\
\hline
\end{tabular}

The scores obtained by students on tests of cognitive domains and science process skills domain, the worksheets provided are very effective for training students' science process skills and knowledge. It is evidenced by a significant increase in the pretest and posttest results of these two domains. The improvement of students' abilities is in accordance with that "students' science process skills can be improved through the guided inquiry learning model" [20]. Therefore, guided inquiry has a significant influence on improving students' science process skills and knowledge.

\section{CONCLUSION}

From the data processing that has been done, conclusions can be drawn that the Student Worksheets developed is valid to use. It can be proven from the validation results have an average of $93.3 \%$. The Student Worksheets developed are also practical to use. The student worksheets that have been given can be seen from student responses to the questionnaire who answered "yes" as many as $98 \%$ of the answers. In addition, in the activities of students, $90.2 \%$ of students performed exercises that were relevant during the learning process. The developed worksheet was also practical to use as the acquisition of pretest and posttest cognitive domains and science process skills. The normality test was both normally distributed, and the paired sample t-test showed a significant difference in the results of the two tests in the cognitive and SPS domains. And then, The Student Worksheets Developed are valid, practical, and effective for use in learning chemistry for the Reaction Rate material and can improve students' science process skills.

\section{REFERENCES}

[1] Murwindra, R., \& Yuhelman, N. (2019). Implementasi Kurikulum 2013 pada Pembelajaran Kimia di MA PP Syafa'aturrasul Teluk Kuantan. JEDCHEM (Journal Education and Chemistry), 1(1), 4455.

[2] Suhesti, D. S. (2019). EVALUASI PELAKSANAAN PEMBELAJARAN KIMIA SMA KURIKULUM 2013. Ideguru: Jurnal Karya Ilmiah Guru, 4(1), 19-24. 
[3] Arantika, J., Saputro, S., \& Mulyani, S. (2019, February). Effectiveness of guided inquirybased module to improve science process skills. In Journal of physics: conference series (Vol. 1157, No. 4, p. 042019). IOP Publishing.

[4] Hidayah, R., \& Anggraeni, L. (2018). The Effectiveness of Guided Inquiry-Based Students Practicum Worksheet to Promote Science Process Skills In Reaction Rate. Proceedings of ICST 2018, 1, 11-13.

[5] Gunawan, G., Harjono, A., Hermansyah, H., \& Herayanti, L. (2019). Guided Inquiry Model Through Virtual Laboratory To Enhance Students' Science Proccess Skills On Heat Concept. Jurnal Cakrawala Pendidikan, 38(2), 259-268.

[6] Gustina, G., Hamsyah, E. F., \& Ahmad, F. (2021, May). Effect of Guided Inquiry Learning Model Assisted by Student Worksheets on Student Process Skills in Biochemistry Course. In 2nd Annual Conference on Education and Social Science (ACCESS 2020) (pp. 357-359). Atlantis Press.

[7] Arends, RI (2012). Learn how to teach. New York: McGraw-Hill.

[8] Ivanova, T., Gubanova, N., Shakirova, I., \& Masitoh, F. (2020). Educational technology as one of the terms for enhancing public speaking skills. Universidad $y$ Sociedad, 12(2), 154-159.

[9] Ahyani, H., Waluyo, R., \& Mahfud, M. Curricullum Management And Assesment System In Basic Education (DIKDAS) Era Of Industrial Revolution 4.0.

[10] Mahyuna, M., Adlim, M., \& Saminan, I. (2018, September). Developing guidedinquiry-student worksheets to improve the science process skills of high school students on the heat concept. In Journal of Physics: Conference Series (Vol. 1088, No. 1, p. 012114). IOP Publishing.

[11] Sugiyono. (2016). Quantitative, Qualitative and R\&D Research Methods. Bandung : PT Alphabet.

[12] Lego, S. (1999). The one-to-one nurse-patient relationship. Perspectives in psychiatric care, 35(4), 4-23.

[13] Nugraha, M. I. M. S., \& Fitrihidajati, H. (2021). Validity Of Ecology Misconception Test Instrument Using Three-Tier Test Method For 10TH-Grade High School Students. Berkala Ilmiah Pendidikan Biologi (BioEdu), 10(3), 627-634.

[14] Aprillia, R. D. (2016). Implementation Of Semi Guided Inquiry Learning Model To
Practice Students'Critical Thinking Skill At Polar And Non Polar Covalent Bonding Topic. UNESA Journal of Chemical Education, 5(1).

[15] Hake, R. R. (1999). Analyzing change/gain scores.

[16] Hariadi, N., Rasmiwetti, R., \& Haryati, S. (2020). Pengembangan Lembar Kegiatan Peserta Didik Berbentuk Majalah Berbasis Berpikir Kritis Pada Materi Laju Reaksi Kelas XI Sekolah Menengah Atas. Jurnal Pijar Mipa, 15(5), 434-437.

[17] Yasmin, N., Ramdani, A., \& Azizah, A. (2015). Pengaruh metode inkuiri terbimbing terhadap keterampilan proses sains dan hasil belajar biologi siswa kelas VIII di SMPN 3 Gunungsari tahun ajaran 2013/2014. Jurnal pijar MIPA, 10(2).

[18] Aryanti, U. R., Bektiarso, S., \& Subiki, S. (2018). Pengaruh Model Pembelajaran Inkuiri Terbimbing (Guided Inquiry) Disertai Process Worksheets Pada Materi Hukum Gerak Newton Terhadap Keterampilan Proses Sains Dan Hasil Belajar Siswa Di Sma. FKIP ePROCEEDING, 3(1), 63-67.

[19] Andriani, D. W. (2018). Melatihkan High Order Thinking Skills Peserta Didik Melalui Implementasi Model Pembelajaran Inkuiri pada Materi Kesetimbangan Kimia. UNESA Journal of Chemical Education, 7(3).

[20] Baiq, F. R. H. (2021). Pengembangan LKPD Berbasis Keterampilan Proses Sains Dalam Model Pembelajaran Inkuiri Terbimbing Materi Struktur Dan Fungsi Jaringan Tumbuhan Di SMP (Doctoral dissertation, Universitas Mataram). 